\title{
Beyond 4.2: Librarian's role in overall NAAC process of the institution in the light of revised framework
}

\author{
Jagdish Narharrao Kulkarni
}

Librarian and I/C Director, Knowledge Resource Centre, Swami Ramanand Teerth Marathwada University, Nanded, Maharashtra, India.

*Corresponding Author: Jagdish Narharrao Kulkarni

Email: Jnkul72@gmail.com

\begin{abstract}
Assessment and Accreditation through National Assessment and Accreditation Council (NAAC) is now obligatory to the higher education institutions. Recently NAAC has revised its assessment process framework. The place of library in the institution has its own importance. The library and the librarian can contribute a lot in the development of the institution and accreditation. The paper discusses the role of librarian and the library in overall NAAC process in the light of revised framework.
\end{abstract}

Keywords: NAAC, Higher education institutions, University, College, Assessment, Accreditation, Library, Librarian.

\section{Introduction}

There is remarkable growth in institutions of higher learning in India. Central, state, deemed, private, foreign, autonomous universities and institutions are growing rapidly in every part of the country. Whenever there is quantitative growth there is need to provide more attention on quality improvement. There are different ways to assess the institutions of learning viz. NAAC, NBA, ISO9001, NIRF etc. The libraries being part and parcel of the institutions of higher learning can perform key role in the improvement of quality of teaching, learning, research and extension activities. The aim of the paper is to discuss role of library and the librarian in the process of NAAC of the parent institution.

\section{Objectives of the paper}

1. To introduce NAAC.

2. To discuss latest developments in NAAC process.

3. To highlight quality indicator framework (QIF).

4. To narrate Library as a learning resource.

5. To enumerate role of Library and Librarian in the NAAC process.

\section{National assessment and accreditation council (NAAC)}

The NAAC is an autonomous institute of the UGC established in 1994 at Bangalore. The core values of the NAAC are contributing to the National Development, Fostering global competencies among students, inculcating a value system among students, promoting the use of technology. The NAAC vision is "To make quality the defining element of higher education in India through a combination of self and external quality evaluation, promotion, and sustenance initiatives". The mission of the NAAC states,

1. To arrange for periodic assessment and accreditation of institutions of higher education or units thereof or specific academic programmes or projects.

2. To stimulate the academic environment for promotion of quality in teaching- learning and research in higher education institutions.
3. To encourage self- evaluation, accountability, autonomy and innovations in higher education.

4. To Undertake quality related research studies, consultancy and training programmes and.

5. To collaborate with other stakeholders of higher education for quality evaluation, promotion and sustenance (NAAC, 2018d).

\section{Developments in NAAC process}

The NAAC assessed and accredited more than 7993 institutions of higher learning. The institutions has to undergo for NAAC assessment after every five years in cycle. Some of the institutions are in fourth cycle of the accreditation. Revised Assessment and Accreditation framework is launched in July 2017. The Shift is.

1. From qualitative peer judgment to data based quantitative indicator evaluation.

2. With increased objectivity and transparency.

3. Towards extensive use of ICT confirming scalability and robustness.

4. In terms of simplification of the process drastic reduction in number of questions, size of the report, visit days, and so on.

5. In terms of boosting benchmarking as quality improvement tool. This has been attempted through comparison of NAAC indicators with other international QA frameworks.

6. Introducing Pre-qualifier for peer team visit, as $30 \%$ of system generated score.

7. Introducing System Generated Scores (SGS) with combination of online evaluation (about $70 \%$ ) and peer judgement (about 30\%).

8. In introducing the element of third party validation of data.

9. In providing appropriate differences in the metrics, weightages and benchmarks to universities, autonomous colleges and affiliated/constituent colleges.

10. In revising several metrics to bring in enhanced participation of students and alumni in the assessment process (NAAC, 2018,c). 


\section{Quality indicator framework (QIF)}

The criteria based assessment forms the backbone of A and A process of NAAC. The seven criteria represent the core functions and activities of a HEI. In the revised framework not only the academic and administrative aspects of institutional functioning but also the emerging issues have been included.

The seven Criteria to serve as basis for assessment of HEIs are

1. Curricular Aspects.

2. Teaching-Learning and Evaluation.

3. Research, Innovations and Extension.

4. Infrastructure and Learning Resources.

5. Student Support and Progression.

6. Governance, Leadership and Management.

7. Institutional Values and Best Practices.

Under each Criterion a few Key Indicators are identified. These Key Indicators (KIs) are further delineated as Metrics which actually elicit responses from the HEIs.

\section{Library as a learning resource}

The library is covered in the fourth criteria Infrastructure and Learning Resources under 4.2 Library as a learning resource with weightage of 20 in overall 1000 weightage divided into seven criteria. The focus of assessment is on the library holdings in terms of books, journals and other learning materials and technology-aided learning mechanisms which enable students to acquire information, knowledge and skills required for their study programs. A recent development in the field due to availability of digital means, the functioning of the library has undergone a drastic change. Automation of library using the ILMS, use of e-journals and books, providing remote access to e-resources in the library have become a matter of necessity. Providing for these and such other developments as well as utilizing them well are important indicators of the quality of an academic institution.

Further it has been divided into metrics with weightage as, Library is automated using Integrated Library Management System (ILMS) (5), Collection of rare books, manuscripts, special reports or any other knowledge resources for library enrichment (2), availability of ejournals, e-ShodhSindhu, Shodhganga membership, ebooks, databases (3), Average annual expenditure for purchase of books and journals during the last five years (INR in Lakhs) (5), Availability of remote access to eresources of the library (1), Percentage per day usage of library by teachers and students (current year data) (4) (NAAC, 2018c).

\section{Role of library and the librarian in NAAC process}

Librarian has to play basic two roles, first as a member of the college team and second one as a leader of the Library. The areas where he can actively participates are, Higher Education Institution (HEI) Registration, Information for quality Assessment(IIQA) Submission,
Self-Study Report (SSR) Submission, Quantitative Metrics (QnM) Assessment For Pre-Qualification, Peer Team Visit (PTV) Management Process, SSR Qualitative Metrics (QIM) and actual Assessment Process by Peer Team (PT).

Further the role of library and the librarian in overall NAAC process specifically beyond 4.2 are,

Librarian supports many activities and these activities may vary according to institutions and the persons. He/She can be a part of the Management viz. President, Vice president, Secretary, member etc. and act accordingly. $\mathrm{He} / \mathrm{She}$ can be member of Local Management Committee, Principal, Vice Principal, Coordinator of NAAC, IQAC and other such committees, further Librarians are also working on Peer team of the NAAC.

Librarian can be anchor, host to plan NAAC related meetings and awareness programs, He/She may help and guide institute in creation of website, web pages, use of ICT etc, Librarian can make available NAAC related literature, self-study reports of other universities and colleges etc.;

Librarian can help in planning, communication, management, presentation and every activity, NAAC and Academic audit has to maintain many types of records library and librarian can support in maintenance of records.

Library supports curricular aspects of the institution by maintaining curriculum of different programs and its supporting documents and upload it on institutional website. Library can introduce/Support Certificate courses/Diploma course. Librarian can be a Senate member, Academic Council member, BOS chairman, member etc. thus Librarian can add to the weightage of the institution. Librarian may support in student's field projects and internships. Librarian can also participate in feedback process as he is in touch with maximum students.

Library can render special services for advanced learners and slow learners. Librarian may help teachers by providing e-resources for their effective teaching with ICT. Librarian can act as mentor of students for academic and stress related issues. Librarian is teacher hence he/she will contribute in percentage of the institute full time teacher with Ph.D. Being full time teacher Librarians awards, recognition, and fellowship at State, National, and International level from government, recognized bodies will add in feather of the institution.

Librarian play an important role getting research projects. In addition, his personal research project will add weightage. Experiences of the librarian should be added in teaching experience. Library can support capability enhancement and development schemes viz. Guidance for competitive examination.

Library can share in Updating IT facilities including Wi-Fi, Facilities for e-content development. Library can establish systems and procedures for maintaining and utilizing library. Librarian can support activities like competitive examinations, Career counseling, soft skill development, Yoga and meditation and Personal Counseling. Effectiveness of Library committee is evident through minutes of meetings and implementation of their resolutions. 
Participation of Librarian and library staff in conferences/workshops with financial support and membership fee of professional bodies. Professional development/administrative training programs organized by the library for teaching and non-teaching staff. The weightage can be added for attending professional development Programs viz., Orientation Program, Refresher Course, Short Term Course etc. by the Librarian.

Library can show gender sensitivity in providing facilities such as: Safety and Security, Counseling and Common Room. Library may support green initiative on the campus by replacing tubes/bulbs with LED bulbs, go for rain water harvesting. Librarian can promote and participate in Green Practices - Students, staff using a) Bicycles b) Public Transport c) Pedestrian friendly roads, Plastic-free campus, Paperless office, Green landscaping with trees and plants, green library project and waste management.

Librarian and Library play major role in making available Braille Software/facilities, in specific and Physical facilities, Provision for lift, Ramp/Rails, Braille Software/facilities, Rest Rooms, Scribes for examination, Special skill development for differently abled students.

Library can take initiative to contribute local community, Library Code of conduct handbook can be prepared for users. Core values can be displayed in the library and on its webpage. Librarian and staff of the library can plan and organize appropriate activities to increase consciousness about national identities and symbols; Fundamental Duties and Rights of Indian citizens and other constitutional obligations. Librarian can introduce or support for offering a course on Human Values and professional ethics. Library profession has professional code which can produced in support.

Librarian and staff of the library are always part of the activities conducted for promotion of universal values(Truth, Righteous conduct, Love, Non-Violence and peace); national values, human values, national integration, communal harmony and social cohesion as well as for observance of fundamental duties.
Library organizes national festivals and birth/death anniversaries of the great Indian personalities e.g. Birth anniversary of Dr. S.R. Ranganthan (Librarians Day), Dr. A.P.J. Abdul Kalam (Reading inspiration day) and Shakespeare (Book and Copyright day). Best practice of the library can be a best practice of the College/Institution. Library or its section can be one area distinctive to its vision, priority and thrust under the performance of the institution.

\section{Conclusion}

The libraries play a major role in catering to the information needs of educational community, Significant role for libraries to lead the parent institutions in pursing new modes of academic research and productivity, Libraries and librarians are base of academic productivity, with a potential to expand both the range and depth of creative work carried out by the faculty and students in corresponding disciplines. Hence library and librarian can play an important role and contribute a lot in the assessment and accreditation process beyond 4.2 i.e. Library learning resource.

\section{References}

1. Deshmukh, S.B. and Kulkarni, J.N. (2016) Role of Librarian in NAAC process in Veer and Sontakke, Advancement and Challenges for College libraries in IT era Deoni Raska college 350-354.

2. NAAC (2018a) NAAC institutional accreditation: Manual for self-study report universities, Bengaluru: NAAC.

3. NAAC (2018b) NAAC institutional accreditation: Manual for self-study report autonomous colleges, Bengaluru: NAAC.

4. NAAC (2018c) NAAC institutional accreditation: Manual for self-study report affiliated/constituent colleges, Bengaluru: NAAC.

5. NAAC (2018d) Official Website www.naac.gov.in accessed on $21 / 11 / 2018$

How to cite this article: Kulkarni J. N, Beyond 4.2:

Librarian's role in overall NAAC process of the institution in the light of revised framework, Indian $j$ Libr Sci inf techno. 2018;3(2):67-69 